\title{
Japanese summary
}

モクズガニの未成体期における鉗脚の相対成長

小林 哲 ·松浦修平

モクズガニEriocheir japonicaの未成体期（甲幅 $40 \mathrm{~mm}$ 未満）における鉗脚の相対成長を, 飼育条件下で明らか にした. 甲幅と鉬脚長節高の関係により, 雌雄とも甲幅 $11 \mathrm{~mm}$ 付近の変曲点により分けられる2つのPhase の存 在が示された. 回帰直線には雌雄ともPhase間に有意差が認められ, また第 1 Phaseに有意な雌雄差が無いのに対 し第 2 Phaseでは雌雄差が認められた. さらに, より大型個体での結果を加えることで, モクズガニの全サイズに わたる針脚の相対成長様式を推定した. 雌雄差の無い 1 つのPhaseのあとに, 雌雄差の拡大するPhaseが, さらに

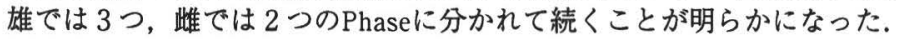

Crustacean Research, No. 25: 1-6, 1996

Natatolana japonensis (Richardson, 1904)（等脚目：Cirolanidae科）の再記載，及びアリソモモブト スナホリムシ Natatolana miyamotoi Nunomura, 1991との関連について

Stephen Keable

等脚目Cirolanidae科モモブトスナホリムシ属Natatolanaは日本近海から 3 種が報告されている．そのうちの 2 種, Natatolana japonensis (Richardson, 1904)を正模式標本に基づき詳細な罒とともに再記載し，アリソモモブト スナホリムシ Natatolana miyamotoi Nunomura, 1991を副模式標本に基づき図示した. この 2 種の模式標本を詳細 に検討した結果, 種レベルの標徴に差は認められず, アリソモモブトスナホリムシ N. miyamotoilN. japonensis のジュニア・シノニムであることが明らかとなった。 よって, 日本近海に分布するモモブトスナホリムシ属 Natatolanaは 2 種となった。

Crustacean Research, No. 25: 7-15, 1996

チゴガニのmound造築

北浦 純 $\cdot$ 和田恵次

砂泥性潮間帯に造穴して生息するチゴガニにおいては, 巣穴から掘り返した砂泥を少し離れた場所や巣穴口近 辺に積み上げたり, 巣穴近辺の砂泥を集めて巣穴口周囲に積み上げる行動が見られる.この砂泥性構築物, mound を巣穴口から離れて配置するのは, ほとんどが甲の堅い雄であったのに対して, 巣穴口に接するように, または 巣穴口を囲むように配置するのは, ほとんどが雌, 特に抱卵雌や雌雄のつがいであった. また, moundを巣穴口 に接するように積み上げていた雌は, moundのない雔に比べて地上活動時間が有意に短かったが, moundを巣穴 ロから離れて配置していた雄の地上活動時間は, moundのない雄のそれと変わりなかった. 大量の雨が降り, 地 上活動の低下した日には, 宩穴口に接して造られるmoundをもつ巣穴の割合が増加した. moundを巣穴口から離 れた場所に配置させるか，巣穴口に積み上げるかは，地上活動の活発性に依存しているようである．

Crustacean Research, No. 25: 16-24, 1996

縁毛目緎毛虫に寄生されたArchaeomysis属アミ類の出現状況

花村幸生・長崎慶三

日本および隣接海域より得られArchaeomysis属アミ類はしばしば体表面に縁毛目織毛虫の寄生を受けていた。

北西太平洋の各地から採集した標本を基に，この緎毛虫の寄生の状況を調べた. 調查した 4 種のArchaeomysis

(Archaeomysis sp., A. kokuboi, A. vulgaris, A. japonica) はすべて繊毛虫の宿主であることが確認された，ただ し，寄生率は種間で差が認められ上記 4 種の寄生率はそれぞれ $74.2,75.6,22.3$ および $1.2 \%$ あっって, 北方性の 種で高い寄生率を示した. また, 同一種内でも北方の個体群において寄生率が高くなる傾向にあった.このこと から, 縁毛類の好寒海性が示唆された。一方, 潮間帯の種は亜潮間帯性の種に比べ明らかに寄生率が高かった。 北海道ではArchaeomysisと縁毛目織毛虫の奇生関係は周年みられる現象であるが, この奇生によってアミ個体群 が著しい減耗を引き起こすような深刻な影響を受けることは無いものと推察される.

Crustacean Research, No. 25: 25-33, 1996 
ニュージーランド, KaikouraのEuryolambrus australisの食性と保護色

Chris M. C. Woods · Colin L. McLay

ニュージーランド, Kaikouraの潮間帯に棲息するEurynolambrus australisの胃内容物は, サンゴモ（Corallina officinalis) が最も主要な構成食物で, 観察個体の $94.6 \%$ (餌の $55.0 \%$ ）に出現した。他には, 紅藻, 緑藻, 褐藻 類, それに等脚類, 端脚類, 十脚類もよく食べられていた。雌雄および採集場所の違う個体間の食物組成には違 いは認められなかった。成長段階による食物組成には違いがあり, 大型個体は十脚類, 腹足類, サンゴモ, 褐藻 をより多く摂餌していたが，小〜中型個体は端脚類を多く食べていた. 胃内容物のうち動物質の多くがサンゴモ 内にみられるものであり，このカニが，擬態を容易にする色素源にもなるサンゴモを食べるように特化している ことを示している.

Crustacean Research, No. 25: 34-43, 1996

Ilyoplax pingiとIlyoplax dentimerosa（スナガニ科：チゴガニ属）の個体群と繁殖

和田恵次 · Byung Lae Choe $\cdot$ Joong Ki Park $\cdot$ Seung Shic Yum

韓国・江華島のある干潟の高潮帯において, チゴガニ属の2種, Ilyoplax pingiとI. dentimerosaの個体群構造と 繁殖生態を調べた. 生息密度は, 概してI. pingi (平均 $238 / \mathrm{m}^{2}$ ) の方が, I. dentimerosa (平均 $159 / \mathrm{m}^{2}$ ) よりも高 かった．抱卵雌は，I. pingiで5月または6月から8月まで出現し，抱卵率は，8月に最大となったが, I. dentimerosa では，4月から8月まで出現し，このうち4月には，ほとんどの成体雌が抱卵するという極端に高い抱卵率を示し た. 稚ガニの新規加入は，I. pingiでは9月から10月にかけて，I. dentimerosaでは $5 \cdot 6$ 月に多く見られた. 両種 とも, 雌は, 生後 1 年で繁殖に参加することが推察された。1雌当たりの卵数は, I. pingi (平均2192) の方が, I. dentimerosa（平均1136）よりも多く，反対に卵サイズは, I. dentimerosa (平均 $0.0248 \mathrm{~mm}^{3}$ ) の方が, I. pingi (平均0.0112 $\mathrm{mm}^{3}$ ) よりも大きかった。ペアー形成は, 再種とも, 雌雄が同一の巣穴に入ることで行われた。 た だし, I. pingiでは, 放浪雌が巣穴所有の雄の巣穴に入る場合が多かったが, I. dentimerosaでは, 逆に巣穴所有雄 が, 一旦自分の巣穴から離れて近くの巣穴所有雌の巣穴に入る場合が多かった.

Crustacean Research, No. 25: 44-53, 1996

台湾におけるフタバピンノPinnotheres bidentatus Sakaiの新記録

Pan-Wen Hsueh · Jung-Fu Huang

これまで基産地である和歌山でのみ分布が知られているフタバピンノPinnotheres bidentatus Sakaiが台湾中央 の西部沿岸で記録されたので, 背甲の色彩を示すために, カラー写真を添えて詳しく記載した．また，遊泳能力 についても言及した。

Crustacean Research, No. 25: 54-58, 1996

日本産ホンヤドカリ属の 1 新種

駒井智幸

函館湾，和歌山および熊本県天草松島から採集された標本に基づき，ホンヤドカリ属の 1 新種P agurus nigrofasciaを記載した。本種は, 北アメリカ西岸に分布するP. samuelis (Stimpson, 1857), P. hirsutiusculus (Dana, 1851), P. venturensis Coffin, 1957，および日本を含む西部北太平洋温帯域に分布するP. filholi De Man, 1887(ホ ンヤドカリ) に近縁であると考えられるが，いくつかの形態的特徵と色彩により容易に識別される. 本新種は函 館湾では周年にわたり潮間帯岩礁で普通にみられるが，他の産地では冬から初春にかけて出現するのみである。 また, これまでの本邦各地における調査にも関わらず, 本新種が採集されたのは上記の 3 力所だけであった.

Stimpson (1858)が, 函館湾からP. hirsutiusculusとして記録したものが実際には本新種であった可能性がある が, 標本はシカゴ火火災の際に失われたものと考えられ, 現在では確認できない. 標本に基づいた hirsutiusculusの本邦における記録は, Stimpson (1858)の他にはYokoya (1933)による津軽海峡の水深110 mから の採集記録があるが, Yokoyaの標本は採集水深が深すぎ, P. hirsutiusculusとも本新種とも異なるものと考えら れる. 最近の文献においても，本邦におけるP. hirsutiusculusの分布は現在のところ確認されていない. 文献の記 録に基づき，P. hirsutiusculusにはエゾホンヤドカリという和名が与えられてきたが, エゾホンヤドカリの分類学 的位置を決定するのは現時点では不可能であり, 本新種には新称ヨモギホンヤドカリを提唱する. 
カニダマシ科の精包および精子の形態学的研究. I. Aliaporcellana suluensis・Pisidia longicornis Christopher C. Tudge $\cdot$ Barrie G. M. Jamieson

カニダマシ科の 2 種, Aliaporcellana suluensisおよびPisidia longicornisの精包と精子の微細構造について研究 を行った．两種とも精包は有柄で球形から卵形で，瓶状体のなかに螺旋状になった少数の非常に長い精子を含ん でいる。瓶状体は 2 分しており，それぞれが複雑な形の，肥厚した側面の隆起部で結合している。両種の精子に は小さく複雑な先体がある. 先体には穴のあいた蓋があり，核質が複雑な同心円状の構造をしている.これまで 報告されている異尾類と比較すると, 先体がこのように幾層にもなった層状構造を呈するのは, カニダマシ科の 精子に固有の形質である. 細長い精子は長い尾部を持っており, これも固有の特徵である微小管の中心部からなっ ている.この尾部の基部は細胞質に取り囲まれ，先端部分は核の鞘に取り囲まれている. 微小管の中心部は，末 端に向かって分かれ，4本以上の外部微小管腕を作り出す. AliaporcellanaとPisidiaにみられるほどんど鞭毛の ように伸長した精子の形態は，これまで報告された十脚類のなかでも特異である.

Crustacean Research, No. 25: 73-85, 1996

ヨモギホンヤドカリ Pagurus nigrofasciaの繁殖生態

五嶋聖治・和田 哲·大森寛史

ごく最近, 新種として記載されたヨモギホンヤドカリの分布と繁殖生態を, 模式産地近くの函館湾葛登支の潮 間帯において調べた. 本種は潮間帯上部の潮線付近の転石域にパッチ状に分布し, 季節的移動は見られない. 4 月から 5 月にかけて, 雄が産卵直前の雌が入っている貝殸をはさみ持つ産卵前ガード行動が観察される. 交尾 . 産卵直後にガード行動は終了する。抱卵雌は 4 月から 2 月の間に観察される。抱卵雌の出現時期とその後の卵の 発達状態から, 主な産卵期は 5 月で, 雌は 1 年に 1 回産卵し, 約 9 カ月間という長期にわたって抱卵することが 明らかになった. 交尾前ガード行動はホンヤドカリ属に普通に見られる行動であるが, 長期にわたる抱卵期間は 同地に生息する同属他種，あるいは他所に分布する同属のそれと比較しても非常に長く，きわだった繁殖特性と いえる.このことは本種の属するホンヤドカリ属は, 種類数の豊富さとともに，その繁殖特性にも多様な面が含 まれることを示唆している.

Crustacean Research, No. 25: 86-92, 1996

数種の保存液および温度条件下におけるヤマトヌマエビ幼生の色素胞の退色

吉川貴志・浜野龍夫・林 健一

$30{ }^{\circ} \mathrm{C}$ よび $2{ }^{\circ} \mathrm{Cにおいた} 8$ 種の保存液（1％，3\%および $5 \%$ ホルマリン，1\%，3\%および $5 \%$ 中性ホルマ リン，50\%エチレングリコール，2.5\%グルタルアルデヒド）にヤマトヌマエビCaridina japonicaの第 1 ゾエアを 収容して遮光し, 腹部に分布する色素胞の退色状況の経時変化を観察した，その結果, ゾエア幼生の色素胞の退 色を防ぐ最も有効な保存方法は， $2{ }^{\circ} \mathrm{C}$ 下においた 1 \%ホルマリン溶液による保存であった。

Crustacean Research, No. 25: 93-97, 1996

中国湖南省産ヌマエビ科ヒメヌマエビ属の 1 新種

郭 照良・鈴木廣志

中国湖南省において, 第 1 著者は近年大型甲殼類の生物地理学的研究を継続している. 1992年 8 月, 多数のヒ メヌマエビ属の未記載の標本が採集された. 本標本は, Caridina mengae, および”C. typus"グループのヌマエビ 類と類似したが, 背側が無歯の短い額角を持ち, 第 1 胸脚の指部が掌部よりも長く, 雄の第 1 腹肢内肢基部に長 い羽状毛を備え, 尾部後縁中央には棘がなく, 第 3 影脚の各節の長さと幅の比によりC. mengaeと区別された. ま た, 雄第 1 腹肢内肢の形状およびその内突起が内肢中央部からでることより, "C. typus"グループの他の 10 種と も容易に区別できた．以上のことから本種をヒメヌマエビ属の 1 新種，C. mengaeoidesとして記載した. 
人工飼育下でのミナミアシハラガニの初期発生

Md. Younus Mia ·諸喜田茂充

ミナミアシハラガニの幼生を室内水槽で飼育し, 各幼生と稚ガニの形態を図解し記載した。脬化幼生は 5 ゾエ ア期と 1 メガロバ期を経て, 稚ガニに変態した。本種のゾエア幼生は, 胸部甲の側棘 (carapacial lateral spine) を有しない点が特徴で, 同属の他種と容易に区別できる。

Crustacean Research, No. 25: 104-120, 1996

\section{イセエビのプエルルスおよび稚エビが利用する岩礁表面の角度および海底からの高さ}

Christopher P. Norman ·森川由隆

千葉県の東京水産大学坂田実験実習場において1991年4月から 1992年12月までの間, イセエビのプエルルスお よび稚エビの生息場所を定期的に調べた，昼間に利用していた岩礁表面の穴の位置, 垂直面からの角度および海

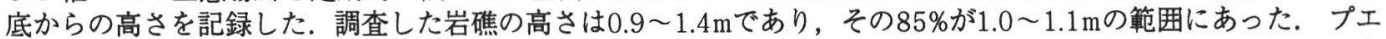
ルルスおよび初齢期の稚エビは岩礁表面において規則的に分布し，より垂直に近い傾斜の穴の方を海底付近や水 平に近い傾斜の穴よりも好んで利用していた。 この傾向は頭胸甲長が8〜 $20 \mathrm{~mm}$ の稚エビも同様であったが, 20 〜 40mmのより大きな個体では認められなかった。これは大型の個体が利用するのに適した穴の数が限られてい

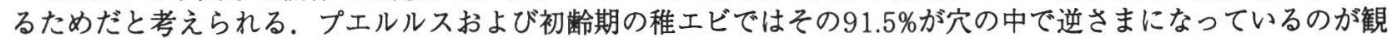
察されたが, 大きくなるにつれてこの割合は減少した.

Crustacean Research, No. 25: 121-128, 1996

日本からの海産等脚目の 1 新種Aega komai（コッブムシ亜目 : グソクムシ科）

Niel L. Bruce

千葉県銚子沖からとられたヤリイカの外套膜に付着していた雄 1 個体に基づき, 新種Aega komaiを詳しい図を つけて記載した．同属他種との比較を行ったところ, 本種は板状に拡がった第 1 触角の第 1 , 第 2 節, 扁平で幅 広い第 2 触角の第 5 節, 短く截形で末端縁に鋸歯のある腹尾節, 同様の鋸崡がある尾肢, さらに第 3 歩脚にだけ ある非常に大きな棘などの特徴により他の種類から区別されることが分かった.

Crustacean Research, No. 25: 129-136, 1996

オョギピンノのはさみ脚の形態変化

大谷拓也 ·高橋 徹

オヨギピンノの成長にともなうはさみ脚と腹部幅の形態変化を, 飼育標本および採集標本を用いて調査した。 はさみ脚指節内側の歯数は, 例外はあるが, 4令から5令にかけて2から1に変化したが, 雌雄のはさみ脚の形態に 違いは見られなかった，2歯を有するはさみ脚の指節はまっすぐで，前節は細く，1歯を有するはさみ脚の指節は 曲がり, 前節は大きかった. 腹部の形態も，4令から5令にかけて性差が現れた．歯の数が成長にともなって, 2 雬から1歯へ変化することは知られていなかったので, 本研究の結果から2歯タイプのT. intermediaは1歯タイプ のT. horvathiのシノニムであると考えられた.

Crustacean Research, No. 25: 137-141, 1996

\section{アメリカザリガニの鉗脚に誘発した過剩再生体の形態}

中谷 勇

アメリカザリガニProcambarus clarkii の鉗脚に種々の形の過㮃再生体を誘発した．前節の一部を側方から神経 幹の 1 本を切断するようにU·字型に切除すると, 前節の基部側と先端側それぞれの傷面から不動指と同様の構造 物が向かい合って形成された.この1対の構造物は，傷の幅が相対的に広いと互いに離れて㧍り，それぞれの鈎 爪と鋸歯は向かい合って形成された。この1対の構造物は，傷の幅が狭いと基部付近で融合しているが先端の方 では二つに分かれるか，または全長にわたって融合した。後者の場合は，それぞれの鍣歯は背側または腹側に並 列に形成されたが, 鈎爪は形成されないか，または，先端に1対の鈎爪が形成されたが，鋸歯は形成されないも のもあった，過㮃再生体に鈎爪も鋸歯も形成されない，単一の棘状の構造物も形成されたが，これは1対の過剩 再生体がより密に融合したものと考えられる．傷口から $2 〜 3$ 対の融合した構造物が形成された個体もあった。 
ブラジルにおける 8 番目の十脚類外来種Charybdis helleriiの記録

Marcos Tavares • Joel Braga de Mendonça Jr.

西大西洋に扔けるCharybdis helleriiは，カリブ海（1987，1988），北東ヴェネズエラ（1987），およびフロ リダ東部（1995）に扮いて外来種として発見されている。新たに本種はブラジルの南東部沿岸（リオデジャネイ

ロ）で記録された，また，ブラジルに抽る本種の出現ならびに他の海産十脚類の 7 外来種について論議した.

Crustacean Research, No. 25: 151-157, 1996

テナガホンヤドカリにおける 1 繁殖期内の交尾個体サイズの時間変異

和田＼cjkstart哲・園田 武・五嶋聖治

テナガホンヤドカリP Pagurus middendorffiiを用いて，1繁殖シーズン内で交尾前ガードに参加している雌雄の 体サイズの時間変動について調べ, また, 大型雄の配偶者をめぐる競争での有利性を実験室内での実験で検証し た．その結果，大型雄は配偶者をめぐる競争で有利であることが明かとなった．また，繁殖シーズンを通して採 集されたガード中の雌雄の体サイズ間でサイズ同類交配の傾向がみられた。サイズ同類交配の傾向は繁殖シーズ ンのピーク期，後期においても見られたが，前期には見られなかった. 雌雄ともに交尾個体の体サイズは繁殖シー ズンの前期から後期にかけて小さくなり，その理由として，雄に関しては現在と将来の繁殖成功度間のトレード オフ, あるいは生理的な制約が示唆され，雌では，繁殖と成長の配分のサイズ依存的な变異，あるいは小型個体 に働く生理的な制約が考えられた。 